\title{
The early-adolescent girl's experience of weight gain: A symbolic interactionism and life-course conceptual framework
}

\author{
Stephna J Lubbe \& Helena M de Klerk*
}

\begin{abstract}
OPSOMMING
Inleiding

In 'n vinnig veranderende Suid-Afrikaanse samelewing, met 'n Westerse klem op 'n slanke vroulike liggaam as die nastreefbare ideaal, en waar oormassa stereotipes ook algemeen gehuldig word en deur die media gepropageer word, raak dit moontlik vir al hoe meer vroeë-adolessente dogters toenemend moeiliker om die toename in massa (tipies in hierdie ontwikkelingsfase) te hanteer - moontlik omdat dit vir die dogter moeilik is om te antisipeer hoe groot en breed haar liggaam gaan word en hoe sy uiteindelik met die gestelde ideaal gaan vergelyk. Toename in massa raak die dogter se belewenis van haar fisieke self. Dit is dan ook algemene kennis dat eetversteurings as gevolg van, onder meer, liggaamsontevredenheid, onder vroeë-adolessente dogters toeneem.
\end{abstract}

Vanuit die literatuur is dit duidelik dat die vroeëadolessente dogter heelwat ontwikkeling op fisieke, kognitiewe en psigo-sosiale vlak ondergaan. Adolessensie, en daarby ingesluit vroeë-adolessensie, is ook 'n tydperk waar die samelewing ander eise aan die individu begin stel. Fisieke veranderinge, waaronder die vinnige groei en veral die skielike toename in massa, mag vir die vroeë-adolessente dogter kommerwekkend en selfs problematies wees, veral in 'n moderne samelewing wat soveel klem plaas op slankheid.

Hoewel daar studies gedoen is met betrekking tot die oormassa vroeë-adolessente dogter, is daar ongelukkig weinig, indien enige, indiepte-studies gedoen met die doel om begrip te kry en te verstaan hoe die vroeë-adolessente dogter nie net oormassa nie, maar spesifiek die toename in massa as deel van die self beleef, asook watter strategieë sy in werking stel ten einde by ' $n$ veranderende fase in haar lewe te kan aanpas. Vir die kledingkundige wat voorkoms vanuit 'n sosiaal-sielkundige perspektief benader, voedingkundiges, gesinsterapeute, kleding-konsultante en ander watter betrokke is by die ontwikkeling van die dogter, behoort begrip met betrekking tot hoe die dogter massa-toename as deel van die self beleef en in interaksie met ander hanteer, van veel waarde te wees in die ondersteuning van die dogter in haar voorkomsbestuur, en ook in die bemagtiging van die dogter ten einde 'n positiewe belewenis van die self in interaksie met ander te handhaaf.

Die simboliese interaksionisme en 'n lewensverloopperspektief dien in hierdie studie as vertrekpunt vir die daarstel van 'n konseptuele raamwerk wat die navorser in staat behoort te stel om die verskynsel in totaliteit te bestudeer, sonder dat slegs enkele redes of oorsake vir die probleem uitgesonder word.

\section{Konseptuele raamwerk}

In die Simboliese Interaksionisme is die mens nie 'n vaste strukturele persoonlikheid nie, maar voortdurend in die proses van verandering en sosialisering. Die mens word in interaksie met ander gesien, en nie as 'n passiewe organisme nie, maar as aktief en dinamies. Menslike handeling word nie net deur sosiale interaksie onderskryf nie, maar ook deur interaksie met die self, wat gesien kan word as 'n objek bestaande uit die fisieke self (die liggaam), waarvan klere as "tweede vel" deel uitmaak, en die innerlike self, wat aspekte soos die persoonlikheidskenmerke, waardes, houdings, emosies en so meer insluit. Die self ontwikkel en verander tydens interaksie met ander mense, wat nie net aan die individu terugvoering gee met betrekking tot die self nie, maar met wie die individu haarself ook vergelyk. Hierdie ander mense sluit in betekenisvolle ander (gesin en geliefdes), verwysingsgroep-ander (groepe waaraan die individu behoort en graag wil behoort en persone/groepe met wie sy identifiseer), en veralgemeende ander (mense in die algemeen, kultuurgroep, stereotipes, modeideaal, en so meer).

Die self word as 'n sosiale objek beskou. Die hede is veral belangrik, en nie soseer dit wat in die verlede gebeur het, of die toekoms waarna uitgesien word nie. Vanuit so ' $n$ siening is die individu se optrede in 'n bepaalde situasie primêr die resultaat van haar belewenis van wat nóú in die situasie aan die gang is, en nie wat vanuit die verlede in die situasie ingebring is nie. Die verlede is wel van belang deurdat dit herroep kan word en nou in die situasie van toepassing gemaak kan word.

Die self is belangrik vir self-kommunikasie, selfbeoordeling en self-kontrole. Self-beoordeling is egter verwant aan die beoordeling deur ander. Wanneer die individu dus oor 'n kenmerk beskik wat deur ander wat vir haar belangrik is, nie waardeer word nie (soos dat sy in massa toeneem), mag dit by die individu 'n negatiewe belewenis van die self in interaksie met ander tot gevolg hê. Die individu is egter in staat om die self te manipuleer en te kontroleer. In situasies waar die self bedreig word, kan sy dus van selfhandhawingstrategieë gebruik maak ten einde die situasie en ook die gepaardgaande emosies vir haarself te verander.

'n Lewensverloop-perspektief lê klem op oorgang-

The early-adolescent girl's experience of weight gain: A symbolic interactionism and life-course conceptual framework 
spunte ("transitions") binne die lewensbane ("trajectories") van 'n individu se lewe. Oorgangspunte verwys na veranderinge in die status van ' $n$ persoon, kan van beperkte duur wees, en die gevolge mag langtermyn wees. Vroeë-adolessensie word algemeen as so 'n oorgangsfase gesien. Lewensbane is langtermyn-patrone van stabiliteit en verandering en sluit dikwels veelvuldige oorgangspunte in. Lewensbane kan ook gedefinieer word as die kombinasie van ' $n$ aantal oorgangspunte in verskillende lewensdomeine wat 'n lewensbaan vorm deur die lewe van die individu. Die vroeë-adolessente dogter sal byvoorbeeld 'n lewensbaan met betrekking tot die belewenis van die self hê. ' $n$ Lewensverloopperspektief beklemtoon die balans tussen stabiliteit en verandering in die lewensiklus van 'n individu.

Een van die mees sentrale beginsels van dié perspektief is die begrip van interafhanklike lewens, met ander woorde dat ' $n$ individu voortdurend met ander in interaksie is. Vanuit 'n lewensverloop-perspektief word die menslike lewe dus regdeur die verloop van die lewe ingebou in sosiale verhoudings met vriende, familie en medewerkers.

'n Lewensverloop-perspektief omsluit konsepte van kontinuïteit en verandering regdeur die lewensverloop van 'n persoon, en sluit historiese en huidige sosiale konteks in. Derhalwe handel dit ook met sake soos aanpassing by gebeure, individuele keuses en besluite en gedwonge aanpassings en keuses wanneer daar met eksterne eise as gevolg van verandering, gehandel moet word.

Vanuit 'n lewensverloop-perspektief neem die vroeëadolessente dogter verantwoordelikheid vir haar eie lewe en besluite wat daaromtrent geneem word. Strategieë van aanpassing is die term wat gebruik word om die rol te beskryf van individuele keuses wat gemaak word om die self te kan handhaaf gedurende veranderinge wat deur die lewensverloop plaasvind.

Vanuit so 'n siening word die vroeë-adolessente dogter in hierdie studie dus benader as 'n aktief denkende wese wat verantwoordelikheid kan neem vir hoe sy haar lewe bestuur en kontroleer. Die feit dat sy die self in interaksie met ander as objek kan beleef, stel haar in staat om die self as objek uit te lig, dit te beoordeel, 'n persepsie daaroor te vorm, met haarself daaroor in gesprek te tree en tevrede of ontevrede daaroor te voel. As objek in interaksie met ander kan die self dus betekenis kry en kan die fisieke self as simbool van bepaalde aspekte van haar innerlike self dien. Ander mense, hetsy betekenisvolle ander, veralgemeende ander of verwysingsgroep-ander speel dus 'n belangrike rol in die ontwikkeling en belewenis van haar self.

Die vroeë-adolessente dogter bevind haar in 'n oorgangstadium van haar lewe wat gekenmerk word deur veranderinge op fisieke, kognitiewe en psigososiale gebied. Hierdie veranderinge mag konsekwensies hê met betrekking tot verskeie van haar lewensbane, waaronder haar belewenis van haar self. Ten einde die veranderinge te kan hanteer en aan- vaar, en na 'n tydperk van verandering weer stabiliteit in haar lewensbane te ervaar, maak die dogter waarskynlik van bepaalde strategieë gebruik ten einde weer beheer in haar belewenis van haar self te ervaar.

As vertrekpunt in 'n fenomenologiese kwalitatiewe studie, behoort so 'n benadering vir die navorser die geleentheid te gee om die vroeë-adolessente dogter in totaliteit te bestudeer ten einde haar gedrag en belewenisse te verstaan. Dit behoort onder meer vir die navorser lig te werp op aspekte soos die verwantskap tussen kognitiewe beoordeling, emosies en handhawing, die rol van ander in die individu se belewenisse en gedrag, die belangrikheid van kulturele stereotipes en stigmas in self-stigmatisering, asook die belangrikheid van massa en massa-toename in die belewenis van die self.

\section{- Mrs SJ Lubbe}

Department of Consumer Science University of Pretoria

\section{- Prof HM de Klerk*}

Department of Consumer Science

University of Pretoria

Pretoria

0002

Tel: 0124202853

Fax: 0124502855

Email: helena.deklerk@up.ac.za

* Corresponding author 


\section{INTRODUCTION}

In a rapidly changing Western society, with its strong emphasis on a slim female body as the ultimate goal, it probably gets increasingly difficult for the earlyadolescent girl to accept the normal weight gain that accompanies the onset of puberty. A major developmental challenge during early adolescence involves adaptations to the physical transformations of puberty. In the same way, the social transition exposes early-adolescents to a wide array of social stressors, and the biology of pubertal growth forces maturing teenagers to come to terms with their changing bodies, including changes in height and weight. As a result of the many physical, cognitive and social changes and necessary adaptations that have to be made, many early-adolescents experience this time of life as a crisis (Gowers \& Shore, 2001). Du Bois et al (1992) and Ge et al (1996) point to the fact that increasing numbers of adolescents experience serious problems in adaptation, resulting in chronic daily stress that have been strongly associated with a wide array of disorders, including, but not limited to, psychological, emotional and behavioural problems.

Early adolescence for girls is the age between thirteen and fifteen, but it could begin as early as age eleven (Twinings, 1998:368; Gowers \& Shore, 2001; Sturdevant \& Spear, 2002). One of the changes that early-adolescent girls may experience negatively is the substantial gain in weight relative to their height (Markey et al (2002). Ge et al (1996) point to the fact that a cultural shift toward thinness as a desirable body type may place early-adolescent girls at greater risk of feeling too big and fat. This may then lead to feelings of depression and lower self-esteem.

Early-adolescents are aware of and concerned about their physical appearance, including the size and shape of their bodies (Blowers et al 2003; Smolak, 2004). Early adolescence is a developmental period marked by not only rapid physical changes (Owens, 2002:493; Sturdevant \& Spear, 2002; Rebelo, 2004:24; Dahl \& Hariri, 2005; Viviani, 2006), but also cognitive (Piaget, 1970:732-734; Mwamwenda, 1996:89; Owens, 2002:532; Rebelo, 2004:26) and socio-psychological changes (Van Niekerk \& Van der Spuy, 1994:63; Scriven \& Stevenson, 1998; Owens, 2002:577). Physical changes, amongst which the gain in weight, is often problematic for early-adolescents, especially in a society that emphasises a thin female body and where overweight and obesity stigmas exist, and accompanying stereotypes are often propagated by the media and shared by reference groups.

The early-adolescent girl also develops on cognitive and socio-psychological levels. She now develops the ability to think in an abstract manner, but often does not have the ability to distinguish between her own and other people's thoughts. She also feels that all other people are constantly focusing on her (Piaget, 1970:732-734; Vander Wal \& Thelen, 2000; Owens, 2002:532; Davison \& McCabe, 2006), with the result that she often feels self-conscious and experiences feelings of shame or sadness (Hoyt \& Kogan, 2001; Blowers et al, 2003). Other people's opinions about physical appearance, especially those of the peer group and the mass media, now become increasingly important in her evaluation and experience of her own appearance.

Early adolescence is also the time when society's expectations for the individual change (Frydenberg et al, 2004; Nounopoulos et al, 2006). The earlyadolescent develops in interaction with others and can therefore not ignore society's perceptions, standards and expectations. In an attempt to understand human development, Havighurst (1972, cited in Rice, 1995:333) developed his psycho-social theory of human development. Havighurst sees adolescent development as a combination of the individual's needs and society's expectations - a set of developmental tasks that the individual has to master in order to be able to effectively function as an adult person. Mastering these developmental tasks during the various developmental stages enables the individual to adapt to changes and prepares her for the next stage. One of the eight most important developmental tasks during adolescence, which also has implications for other socio-psychological tasks, is the acceptance of the physical self. For the early-adolescent girl it means that she has to positively accept the physical changes that are taking place, including the gain in weight, and has to develop strategies that can support her in her endeavours to accept the new physical self and develop a positive body image and self-esteem (Compas et al, 2001; Frydenberg et al, 2004; Murberg $\&$ Bru, 2005).

Although a considerable body of research has been done with regard to various aspects of earlyadolescent development, little has been done with regard to the early-adolescent girl's experience of weight gain as part of the experience of self. The question is: How should one approach the problem in totality so as to be able to understand the role of weight gain in the early-adolescent girl's experience of self, including the emotions that she now experiences and the strategies that she employs in order to cope with her situation?

We argue that the early-adolescent girl's body cannot be separated from the rest of her self. Accepting or not accepting physical changes, such as gaining weight, and experiencing it positively or negatively, would therefore also have consequences for how she experiences the rest of the self. We also believe that it is not only about her own perceptions, standards and experiences, but also about those of others and society, and in this case then specifically their viewpoints on weight. Our point of departure therefore asks for a conceptual framework that focuses on the early-adolescent girl's socio-psychological and cognitive experiences of weight. We believe that combining symbolic interactionism and a life-course perspective provides the opportunity for the prospective researcher to study the early-adolescent girl in her entirety, understanding her experiences and behaviour, instead of merely trying to identify a few factors or possible causes for her behaviour. 


\section{SIMBOLIC INTERACTIONISM AND A LIFE- COURSE PERSPECTIVE AS BASIS FOR THE PROPOSED CONCEPTUAL FRAMEWORK}

\section{Symbolic interactionism}

Symbolic interactionism focuses on the active, dynamic interaction between people. In doing so, it creates an active image of the human being and rejects the image of a human being as a passive organism. This implies that human beings are acting in relation to one another (Charon, 1998:23).

The self as ever-changing social object There are many views of the self in psychology and the term self is used in many different ways. In the symbolic interactionist perspective, the concept of self has a very special meaning, and the concept of self has always been regarded as one of the main contributions of symbolic interactionism to psychology. For the symbolic interactionist, the self is an object, and the actor or person interacts with it. Symbolic interactionism focuses on the dynamic social activities that take place when individuals interact with other people or with the self. By focusing on the active dynamic interaction between people, it creates an active image of the human being and rejects the image of a human being as a passive organism (Charon, 1998:23). It implies that human beings are acting in relation to one another. Blumer (1966) describes this process of interaction as follows: "The peculiarity consists in the fact that human beings interpret or 'define' each other's actions instead of merely reacting to each other's actions. Their 'response' is not made directly to the actions of one another but instead is based on the meaning which they attach to such actions."

Human beings are viewed as acting in the present and being influenced by what is happening in the present. The past may, however, enter the situation when it is recalled and applied, but what the human experiences, is linked to what is now going on in each specific situation. The individual, who is conceptualised as active, dynamic and continually in a process of changing, interacts with society and the group. Interaction is therefore not only seen as what is happening between people, but also as what is happening within the individual (Charon, 1998:23).

From the symbolic interactionist point of view, like all other social objects, the self can then acquire meaning and can become and be experienced as a symbol - a social object that represents whatever people agree that it shall represent. According to such a viewpoint, the self as a symbol is then used purposively to give meaning to others and to the self. The individual is able to get outside the self and look back at the self objectively, as an object like all other objects, defined in interaction (Stone, 1962:88-89; Goffman, 1959:11; Hewitt, 1979:71; Charon, 1998:67).

From a symbolic interactionist point of view, there is no self at birth, only a responding organism, because the capacity for self-reference is dependent on developing the ability to use and respond to symbols. Mead
(1934:152-153) sees the first stage as a preparatory or pre-symbolic stage, and refers to the second stage as the play stage, where the child, who is learning language, is able to label and define objects according to the meaning shared by significant others. Early adolescence falls under Mead's third stage, referred to as the game stage, and represents the ability to assume the perspectives of several others simultaneously - the ability to take on a group culture or a group perspective. The individual now has the ability to incorporate all significant others into one generalised other - also named "them" or "society". Interaction now also means interaction with "their" rules and perspectives. The self now becomes an object defined by the individual as measured, not only against the viewpoint of one significant other, but also by "them", or several others. Charon (1998:69-70) describes the development of a generalised other as the internalisation of the concept of society as the individual has come to know it. The individual shares society's viewpoints and perspectives such as stereotypes and social stigmas, and these then become part of the self.

Shibutani (1955 \& 1962:129-144) prefers to see Mead's game stage as the reference group stage, which is especially applicable in an industrial urban mass society. Individuals interact with and share perspectives with many different groups, and thus have several reference groups (social worlds or societies) with whom they constantly interact. The reference group that the individual then interacts with becomes his or her generalised other. Such a viewpoint underlines the work of James (1915:179), who pointed out that "[a] man has as many selves as there are individuals who recognise him". Mead (1934:142) elaborated: "We divide ourselves up in all sorts of different selves with reference to our acquaintances. There are all sorts of different selves answering to all sorts of different social reactions." Hewitt (1979:105) points to the fact that individuals have in a certain sense a limited choice when it comes to others with whom they interact. These limitations stem in part from the facts of birth and role-ascription. One should, however, note that individuals have the choice of using people that they interact with as significant others or as generalised or reference group others. If people with whom the individual interacts are not significant, then their perceptions and definition of the self are not important.

With regard to the early-adolescent girl's experience of weight, the above implies that the early-adolescent girl is now in the so-called game or reference group stage, where she does not only interact with significant others, but interacts and shares perspectives (also on weight) with many other people and groups, who now become her generalised others and who also play an important role in her viewpoint of, and her experience of, her self.

It is important to note here that self should not be identified with body. Mead (1934:136) clarifies the difference by saying: "We can distinguish very definitely between the self and the body. The body can be there and can operate in a very intelligent fashion 
without there being a self involved in the experience. The self has the characteristic that it is an object to itself and that characteristic distinguishes it from other objects and from the self." When the body stands out and becomes an object, gets meaning and is consciously experienced, it becomes part of the self. James has already in 1890 referred to the body as the "Physical Self" (James, 1961:115). The individual experiences the self (including the body) from the particular viewpoints of other members of the same social group, or from the generalised or reference group's perspectives.

The importance of the physical self (body) should not be underestimated. Because our bodies have a material base, we can treat them as part of the self, as we would treat other objects (March, 2000). Turner (1984:38-39) sees the body as similar to a vehicle for carrying around that part of the self that one cannot see or touch, the individual's thoughts, emotions, perceptions and attitudes (inner self). The body as part of nature and part of culture may then be regarded as a link between an inner self and some of society's most important values. That means that the individual experiences both the physical self and the inner self as part of the self, and is able to see either of them as an object that has meaning, that can be judged and labelled in relation to, and against the viewpoints of all others with whom the individual interacts. Stone (1962:86-91) prefers the term "appearance", which includes the size and the shape of the body, and underlines the importance of appearance in communication with others and with the self. He emphasises the importance of the physical self in communication (although non-verbal) and in the maintaining of the self: "Every social transaction must be broken down into at least two analytic components or processes appearance and discourse; appearance is at least as important for the establishment and maintenance of the self as is discourse."

With regard to the early-adolescent girl, such a viewpoint implies that the body, as physical self, is experienced as part of the self. When the body stands out and becomes an object due to, amongst others, many physical changes that are now taking place, it gets meaning, is constantly experienced and becomes part of the early-adolescent girl's self. Weight and weight gain during early adolescence can therefore not be separated from the body and therefore also not from the adolescent girl's experience of self. If one then accepts the body and its weight as part of culture, as a link between the inner person and some of society's most important values, it means that the earlyadolescent girl experiences, judges and labels her body and weight in relation to and against the viewpoints of all others with whom she now interacts.

Self-communication, self-perception, selfjudgement and self-control The self is important for self-communication, for self-perception, for self-judgement and for self-control. It directs what humans experience or see, how they interpret it and how they direct and change their behaviour accordingly. One of the most important functions of the self is to serve as an object of symbolic self-interaction.
Blumer (1966) states that the possession of a self provides the human being with a mechanism of selfinteraction with which to meet the world". The individual is now able to communicate with her self, to think about the self, to point things out to the self and to interpret situations. The essence of self is thus cognitive and lies in the internalised conversation of gestures, which constitutes thinking (Mead, 1934:173). The individual is now able to talk to the self and to evaluate, criticise or compliment the self. The self now gets meaning and, as a social object, thus becomes a symbol for the individual.

The above means that the individual is now able to indicate to the self information about the self in a particular situation. The individual now has selfhood, which implies the ability to visualise the self in a situation and to get a perception of the self, also called self-perception. Callero (2003) points out that, from a symbolic interactionist point of view, the social construction of selfhood is about meanings and understandings associated with the public self - the self that is visible and is known. Self-perception is therefore only possible because the individual is able to compare the self with others and is also able to interpret the feedback from others about his or her self.

Cooley (1970:184) describes self-perception as an important reality that influences the individual's behaviour. He calls it the "Looking-glass self" and explains: "As we see our face, figure, and dress in the glass, and are interested in them because they are ours, and pleased or otherwise with them according as they do or do not answer to what we should like them to be; so in imagination we perceive in another's mind some thought of our appearance, manners, aims, deeds, character, friends, and so on, and are variously affected. A self-idea of this sort seems to have three principle elements: The imagination of our appearance to the other person; the imagination of his judgment of our appearance; and some sort of self-feeling, such as pride or mortification."

From the work of Cooley, it is then clear that the person's experience or perception of the self firstly includes an aspect of judgement against the person's own imagination of the self as presented to others, and also against the imagination of others' judgement of the self. It secondly includes an aspect of emotion, such as shame, satisfaction or pride. Crossley (2006:27) underlines the importance of others in our perceptions and experiences of self, in this case the early-adolescent girl's experience of weight as part of the Physical self: "The self is in many respects its own blind spot. The I does not see itself any more than the eye sees itself and we are therefore reliant upon others to reflect back information about ourselves."

In addition to Cooley's viewpoint of the Looking-glass self, Festinger (1954) adds that human beings have the need to compare themselves to others, which, from a symbolic interactionist viewpoint, may be the significant, or generalised or reference group others. The individual talks to the self about how it compares to others. The result is, according to Shibutani (1961:434-435), again self-judgement. It is, however, 
important to note that this self-judgement is not constructed from the individual's interaction with people in general, but only with those that he has chosen as his significant others or reference groups.

With regard to the early-adolescent girl the above implies that her body with its weight, as part of the self, serves as an object of symbolic self-interaction. The early-adolescent girl is able to talk to herself about the self (including her weight or weight gain) in the same manner that she talks to others. As it gets meaning as a social object, the weight or weight gain may therefore become a symbol of aspects of the inner self. The importance of weight or weight gain as part of body and self, and in the end in the perception that the early-adolescent has of her self, is clear.

Self-judgement is highly related to the judgement of others. Goffman (1963:14-60) describes the situation and the process by which the individual's world is redefined and judged by others, as follows: "Society establishes the means of categorisation of persons and the complement of attributes felt to be ordinary and natural for members of each category. When the individual possesses an attribute that makes him different from others in the category, he is reduced in the minds of others ... from a whole and usual person to a tainted, discounted one."

A stigmatised person thus possesses an attribute or characteristic that conveys a social identity that is devalued in some particular context. Such an individual is ascribed deviant labels and faces negative effects as a result of discrimination and prejudice. Such an individual therefore experiences and judges the self as bearing some kind of mark that makes her different from the norm. Such an experience of the self may have definite consequences for the individual's behaviour. Klaczynski et al (2004) point to the fact that the numerous Western beliefs and stereotypes about weight and obesity may lead to prejudice and discrimination, and that a prominent feature of the belief systems that pervade modern postindustrial societies, is the view that accomplishments and failures are outcomes of personal motivations (or the lack thereof) to be successful. This emphasis on individualism has implications for the social lives of overweight or obese early-adolescents, and also implications for those who experience themselves as being overweight and therefore stigmatising themselves. There are widespread perceptions that obese individuals are responsible for being overweight and that gaining or losing weight is under one's personal control. Obesity, being overweight, or weight gain is therefore often associated with laziness and low selfdiscipline, to the extent that it has become a stereotype. According to Quinn and Crocker (1999) and Puhl and Brownell (2003a \& 2003b), the notion that people get what they deserve in life is central to attributional explanations of weight stigma. The Protestant work ethic (Quinn \& Crocker 1999; Puhl \& Brownell, 2003a \& 2003b) and "just world bias" are two related phenomena. The Protestant work ethic contains the belief that hard work and determination lead to success. It therefore places a high premium on self-control, and blames victims who do not suc- ceed for not conforming to the set norms of being thin. Researchers such as Tomaka and Blascovich (1994) and Puhl and Brownell (2003a) argue that the "just world bias" also portrays the world as a predictable environment in which personal effort and ability lead to the desired outcomes. The tendency to associate positive qualities with physical attributes may be related to just world beliefs. These beliefs increase respect for physically attractive people, or those conforming to the cultural norm of being thin. This leads to the "what is beautiful (thin), is good" stereotype in which physically attractive people, or those who are conforming to the cultural norms, are ascribed more positive qualities than unattractive individuals or those who do not conform to the cultural norm.

From a symbolic interactionist point of view, experiencing a stigma means that the individual experiences some aspects of the self as being different from the selves of others whose opinions and attitudes are important to her. However, if one part of the self is focused on, or is threatened, it will probably also impact on the other parts of the self. Jones et al $(1984: 137)$ therefore state clearly that such a mark or stigma will seldom remain confined to just one aspect of the self: "Marks are easily elaborated in the stigmatising process to play a more central role in the selfdefinition." If the individual experiences that part of the self that gets stigmatised as very important, it will therefore impact more negatively on all the other parts and on her definition of the total self. Any form of labelling may then lead to the question, "is there something wrong with me?" If one accepts Goffman's (1959:66) viewpoint that humans, as actors, are highly self-conscious, then under certain conditions, marked actors or those who have stigmatised themselves, become more so and must work to overcome obstacles that undermine their realising a recognisable, competent self.

Because of the fact that the development and maintenance of the self are dependent on others, the construction or maintenance of a stable and coherent self may be a particularly difficult process for the marked person, or the one who has marked the own self. The early-adolescent girl who experiences weight gain or a changing body negatively, or who experiences herself as fat, may therefore stigmatise herself and may find it difficult to construct and maintain a stable and coherent self. Goffman (1963:135-139) and Jones et al (1984:196-197) underline the importance of having some control over one's behaviour as crucial for the management of desired presentation of the self. In order to do so it is therefore important for stigmatised persons to find a way of arranging their interactions with others to their own advantage. In order to cope with a stigma and acquire within a given situation a feeling of self-worth, the stigmatised person therefore usually relies on certain coping strategies (Goffman, 1963:135-139; Puhl \& Brownell, 2003a \& 2003b).

\section{Coping with a stigmatised self}

In a society that devalues overweight, the early-adolescent girl who has gained weight or who experiences herself as overweight, may stigmatise her self and may experience the self negatively. From a symbolc interaction- 
ist point of view it is, however, not only the body that is stigmatised. William James (1961:65) emphasised emotional experiences as the central characteristic of self-hood. Any changes in the body therefore also have consequences for emotional and cognitive experiences. The early-adolescent girl who experiences sudden weight gain or who experiences herself as overweight, may therefore now also experience negative emotions such as shame because of the weight gain, or anger because of her changing body. Lewis (1971:56 \& 1992:88) and Weiner (1986:151-153) view the emotion of shame as the result of a selfjudgement against an internalised or cultural standard that the individual feels she cannot meet. Crozier (1998) points to shame as a social emotion where the individual feels ashamed about the self and feels that she has failed as an individual, while Lazarus and Lazarus (1994:41-63) refer to shame as an existential emotion and therefore a threat to the positive experience of the self; thus there is a need to employ strategies to cope with the situation and accompanying emotion.

According to Lazarus and Folkman (1984:134), coping can be seen as the individual's efforts to experience control in any given situation, and may include any cognitive or behavioural attempts that a person chooses in order to manage a stressful situation and the accompanying emotion. Coping strategies could be either problem-based or emotion-based. Problembased coping strategies focus on the problem with the aim to either manage or resolve the problem. Emotion-based coping strategies are those strategies that the person chooses with the main purpose of handling the emotions that accompany the specific problem (Forman, 1993:11-13). Lazarus and Lazarus $(1994: 66)$ and Weiner (1986:152) point to the fact that the individual usually finds it very difficult to cope with a devastating emotion such as shame, and usually feels that something should be done to change the situation for herself and/or for others, such as to withdraw from the situation or to hide from it, or to avoid the situation. Anger, on the other hand, is a much stronger emotion, and usually leads to a more active coping strategy and a feeling of power or control of the situation. It should, however, be noted that various factors have an influence on which coping strategies are mobilised under specific circumstances, amongst others, age and gender (Halstead et al, 1993; Piko, 2001; Broderick \& Korteland, 2002; Hampel \& Petermann, 2005). In order to cope with the experience of weight gain and the accompanying emotions, and to acquire a feeling of self-worth, the early-adolescent girl may therefore engage in coping strategies that may have devastating consequences for the development of the self and the mastering of important developmental tasks that could enable her to adapt to other changes during this stage, and prepare her for the next stage.

\section{Life-Course perspective}

The life-course perspective has attained a remarkable degree of institutionalisation in contemporary social theory and research. The rapid growth of this perspective and its multi-disciplinary nature have contrib- uted a diversity of meaning to it. The essence of a life-course approach lies in the continuous interplay between social change and the life course of individuals. It addresses the dynamic interface between lives and social structures over time (Marshall \& Mueller, 2004:20). Such a viewpoint is clearly compatible with the viewpoints of symbolic interactionism, namely that the self, as a dynamic and ever-changing social object, develops in interaction with others. Without others, there can be no self, and the early-adolescent girl's experience and perception of self, including the body and weight gain, are only possible because she is able to compare herself to others and is able to interpret the feedback from others about the self. Elder and Elder (1994) view the life course as a developmental theory. Elder (1998) has provided what is probably the most systematic formulation of the principles and concepts of the life course, and his principles have been widely published.

\section{Fundamental principles of a life-course perspec-} tive A first fundamental principle notes that human development and aging are lifelong processes. It should be recognised that lives are lived the long way and that aging happens across the lifespan. Earlier experiences and the meanings attached to them are carried into new situations. The impact of an event or transition (such as early adolescence) in life is thus shaped by this concept of personal biography (Elder et al, 2003:1-5). With regard to the earlyadolescent girl who now experiences a sudden gain in weight, such a viewpoint implies that the girl's actual weight when entering early adolescence could also play a role in the way that she now experiences weight gain. The girl who has entered this stage with a normal weight may therefore experience the sudden weight gain differently from the girl who has entered this stage as already overweight.

A second fundamental principle of a life-course perspective states that the life course of individuals is embedded in, and shaped by, the historical times and places they experience over their lifetime. An individual's own developmental path is therefore embedded in and transformed by conditions and events occurring during the historical period and geographic location in which the person lives. With regard to historical time and place, symbolic interactionism states that individuals are born into groups, organisations and societies that have been around for a long time. The individual also interacts with collectives of individuals, each as a society, sharing, cooperating, solving problems and communicating. However, each has a history and therefore not every interaction is a brand new situation, but is influenced by preceding interaction. Perspectives and rules are therefore developed historically. The individual learns them in interaction and they often influence how the individual acts in a given situation. Socio-cultural ideologies such as stereotypes and stigmas can therefore shape people's perceptions and choices. Our experiences, behaviour and decisions do not occur in a vacuum, because we interact with others within socio-historical time. With regard to the early-adolescent girl's experience of weight, it implies that it is not only about her own perspectives or those of the significant others in 
her life, but also about the viewpoints, stereotypes and stigmas of all other societies (reference groups and generalised others) that she interacts with.

A third fundamental principle of a life-course perspective underlines the fact that both timing (when they occur) and sequencing (the order in which they occur) of life events condition the effects they have on the subsequent life course (Heinz \& Marshall, 2003:10). Segelken (2005) adds that people can only adapt in ways that are known to them at a specific time, and can only use types of strategies that are available at that particular age and time. Time can also be envisioned as a sequence of transitions over time. A transition is a discrete life change (such as early adolescence) or event within a trajectory (which may be defined as a sequence of linked states within a conceptually defined range of behaviour or experience). A trajectory is therefore a long-term pathway or pattern of stability and change, and can include multiple transitions. Transitions are therefore always part of social trajectories. For the early-adolescent girl, such a view implies that when and how early adolescence occurs for her, would affect long-term pathways (trajectories) of her life course, such as her eating behaviour, relationships, perception of her self and the coping strategies that she employs. It is important to note here that, from a symbolic interactionist point of view, it is not about the effect of the transition or event (in this case, the changes that take place during early adolescence), but rather about the earlyadolescent girl's interpretation and experience of these changes and the meaning that she attaches to the changes. Weight gain as part of the self is then not only a sign of physical change, but becomes a symbol of other aspects of the self. Such a viewpoint has major implications for the study of the earlyadolescent girl's experience of weight and the possible role that it may play in her experience of self and in her behaviour during this transition period.

As is the viewpoint of the symbolic interactionism, the life-course perspective holds the principle that "lives are lived interdependently and social-historical influences are expressed through this network of relationships" (Marshall \& Mueller, 2004:10). Societal and individual experiences are linked through the family and the network of shared relationships (education, work, etc.) (Elder, 1998). Such a viewpoint holds that our behaviours are determined by, and in turn influence, the behaviours of those to whom we are closely linked. It should, however, be noted here that from a symbolic interactionist point of view, behaviours are not determined by others and their behaviours. It is again not about effect, but about the meanings that are attached to occurrences, others and their behaviours. That implies that, without an understanding of mind, symbols and self, human behaviour cannot be understood for what it is.

A life-course perspective underlines the principle of human agency - the principle that "individuals construct their own life course through the choices and actions they take within the opportunities and constraints of history and social circumstances" (Marshall \& Mueller, 2004:11). Individuals are seen as active humans who not only mediate the effect of social structure but also make decisions and set goals that shape social structure. From a symbolic interactionist point of view, this points to the importance of selfcontrol and self-direction. Because of the fact that the self is an object, it is open to self-manipulation. The individual therefore does not merely respond to occurrences, commands and others' behaviours, but has the freedom and ability to always direct and control the self -against the viewpoints of and guided by the viewpoints of others. While the symbolic interactionism underlines the importance of significant others and reference group or generalised others, a lifecourse perspective stresses the role of families: families and individuals modify their expectations and behaviour in response to changes in either needs or resources. It should, however, be kept in mind that human lives are never fully shaped or determined by social circumstances. Individuals are seen as thoughtful, pro-active and self-controlled beings that are able to make their own choices, but depending on opportunities and constraints. For the earlyadolescent girl, such a viewpoint implies that, in order to cope with the weight gain and possibly accompanying emotions, she can only use coping strategies that are available to her during this specific developmental stage and against her cognitive development (Lazarus \& Folkman, 1984:181-223; La Greca et al, 1992:13-17; Compas et al, 2001; Hutchinson et al, 2005). A full understanding of the individual's experience of self therefore requires a broad conceptualisation of context that extends beyond the immediate definition of the situation to include the historical and cultural settings where unarticulated assumptions about the nature of the person have their origin.

\section{PROPOSED CONCEPTUAL FRAMEWORK}

According to Babbie and Mouton (1998:107-113), the value of a soundly considered conceptual framework, based on well-founded theory, where the indicators and possible relationships are present and which includes the research questions, is to be found in the fact that it arranges the research, assists the researcher to reach the research goals and to elicit results which in turn will be a contribution towards establishing new theory. In the opinion of the researchers the suggested conceptual framework, as illustrated in Figure 1, can be usefully applied in qualitative research aimed at a better understanding of the role that weight or weight gain plays in the earlyadolescent girl's experience of self.

From a human developmental point of view, the life of an individual can be divided into various developmental stages that are characterised by physical, cognitive and socio-psychological changes. During the life course of an individual (the early-adolescent girl), there are times of change and times of stability, as is indicated in the schematic conceptual framework (Figure 1). Early adolescence can be seen as a transition (a time of change) in the life of the girl, when major physical, cognitive and socio-psychological changes take place. One of these changes is a sudden and rapid gain in weight, which might, especially in a society that favours a slim female body, play a 


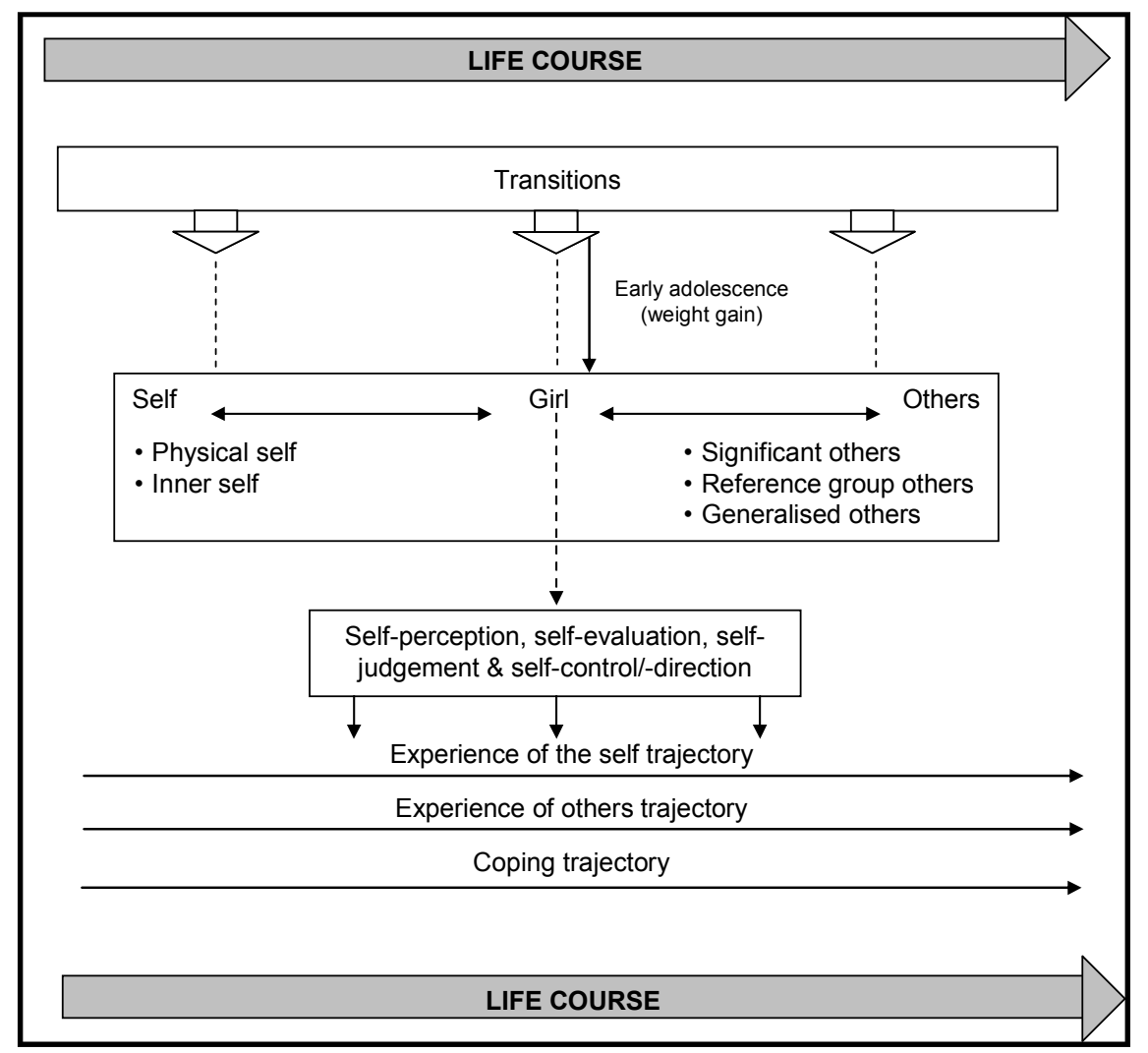

FIGURE 1: PROPOSED SCHEMATIC COCEPTUAL FRAMEWORK

role in various trajectories or paths in her life, such as the way that she now experiences the self, the way that she experiences others and the way that she copes with the changes that are taking place. However, from a symbolic interactionist point of view, it can be argued that the early-adolescent girl is always in interaction with others who may play a role in her life and whose viewpoints are important in the way that she forms a perception of the self, the way that she evaluates and judges the self, as well as the way that she controls and directs the self. These others who give feedback on her physical self (including the gain in weight) or to whom she compares herself, include significant others (such as parents and family), reference group others (such as the peer group), and generalised others (such as the fashion ideal of the time, mass media and stereotypes shared by society). From a symbolic interactionist point of view, it can further be argued that, when the body as physical self stands out, changes or is being evaluated, it becomes an important part of the total self. The body therefore does not stand apart from the rest of the self. The early-adolescent girl's experience of changes in her body, such as weight gain, may therefore also have consequences for her experiences of aspects of her inner self, such as her emotions or the type of person that she feels she is turning into. From a symbolic interactionist point of view, the earlyadolescent girl is, however, also constantly in interaction with the self. She evaluates the self in the same way that she evaluates other social objects, she forms a perception of the self (both the physical and inner self), may reason about the changes that are now taking place and may seek reasons and answers for the changes and for others' reactions to the changes. She may attach new meaning to her changing body, may use it as a symbol of aspects of the inner self and may experience the changes (including the weight gain), and others' reactions to the changes, as positive or negative for the self. From a human developmental and life-course point of view, changes force the individual to find strategies to cope with them, in order to move forward to times of greater stability in life's trajectories. The earlyadolescent girl now has to seek coping strategies that will enable her to deal with the problem of weight gain as well as the accompanying emotions, so as to be able to accept the new physical self, experience the self as positive and move towards a more stable stage in her life course.

\section{CONCLUSION}

We believe that the above approach, as point of departure in a phenomenological qualitative study, provides the opportunity for the family ecologist, nutritionist, clothing specialist or researcher who is interested in the well-being of the early-adolescent, to study the early-adolescent girl in her entirety, understanding her experiences and behaviour, instead of merely trying to identify a few factors or possible causes for her behaviour. It could, amongst others, shed light on aspects such as possible relationships between cognitive appraisals, emotions and coping behaviour, the role of others in the early-adolescent girl's experiences and behaviours, the importance of cultural 
stereotypes and stigmas in self-stigmatisation, the importance of not only weight gain but also of weight as such in the individual's experience of self, and the early-adolescent girl's cognitive and emotional ability to employ coping strategies that can support her during an important developmental stage of her life.

\section{REFERENCES}

BABBIE, E \& MOUTON, J. 1998. The practice of social research. Cape Town. Oxford.

BLOWERS, LC, LOXTON, NJ, GRANDY-FLESSER, M, OCCHIPINTI, S \& DAWE, S. 2003. The relationship between socio-cultural pressure to be thin and body dissatisfaction in pre-adolescent girls. Eating Behaviours 4(3):229-244.

BLUMER, H. 1966. Sociological implications of the thoughts of George Herbert Mead. American Journal of Sociology 71:534-544.

BRODERICK, PC \& KORTELAND, C. 2002. Coping style and depression in early adolescence. Relationships to gender, gender role and implicit beliefs. Sex Roles 46(7/8):201-213.

CALLERO, PL. 2003. The sociology of the self. Annual Review of Sociology 29:115-133.

CHARON, JM. 1998. Symbolic interactionism. 6th ed. New York City. NY. Prentice Hall.

COMPAS, BE, CONNOR-SMITH, JK, SALTZMAN, H, THOMSEN, AH \& WADSWORTH, ME. 2001. Coping with stress during childhood and adolescence. Problems, Progress, and Potential in Theory and Research 127(1):87-127.

COOLEY, CH. 1970. Human nature and the social order. New York City. NY. Schocken Books.

CROSSLEY, N. 2006. The networked body and the question of reflexivity. In Vaskul, D \& Vannini, P. (Eds). 2006. Body embodiment. Aldershot. UK. Ashgate.

CROZIER, WR. 1998. Early adolescentconsciousness in shame. The role of the "Other". Journal for the Theory of Social Behaviour 28(3):273286.

DAHL, RE \& HARIRI, AR. 2005. Lessons from G. Stanley Hall. Connecting new research in biological sciences to the study of adolescent development. Journal of Research on Adolescence 15:367-382.

DAVISON, TE \& McCABE, MP. 2006. Adolescent body image and psychosocial functioning. The Journal of Social Psychology 146(1):15-30.

DU BOIS, DL, FELNER, RD, BRAND, S, ADAN, AM \& EVANS, EG. 1992. A prospective study of life stress, social support and adaptation in early adolescence. Child Development 63:542-557.

ELDER, GH. (Jr). 1998. The life course as developmental theory. Child Development 69(1):1-12.

ELDER, GH (Jr), JOHNSON, MK \& CROSNOE, R. 2003. The emergence and development of life course theory. In Mortimer, JT \& Shanahan, MJ. (Eds). 2003. Handbook of the Life Course. New York City. NY. Kluwer Academic/Plenum.

ELDER, H \& ELDER, GH. (Jr). 1994. Time, human agency and social change. Perspectives on the life course. Social Psychology Quarterly 57(1):4-15.

FESTINGER, L. 1954. A theory of social comparison processes. Human Relations 7(2):117-140. FORMAN, SG. 1993. Coping skills interventions for children and adolescents. San Francisco. JosseyBass Publishers.

FRYDENBERG, E, LEWIS, R, BUGALSKI, K, COTTA, A, McCARTHY, N, LUSCOMBE-SMITH, N \& POOLE, C. 2004. Prevention is better than cure. Coping skills training for adolescents at school. Educational Psychology in Practice 20(2):117-134.

GE, X, CONGER, RD \& ELDER, GH. (Jr). 1996. Coming of age too early: Pubertal influences on girls' vulnerability to psychological stress. Child Development 67:3386-3400.

GOFFMAN, E. 1959. The presentation of self in everyday life. Englewood Cliffs. NJ. Allan Lane.

GOFFMAN, E. 1963. Stigma. Englewood Cliffs. NJ. Prentice-Hall.

GOWERS, SG \& SHORE, A. 2001. Development of weight and shape concerns in the aetiology of eating disorders. British Journal of Psychiatry 179:336-343.

HALSTEAD, M, JOHNSON, SB \& CUNNINGHAM, W. 1993. Measuring coping in adolescence. Journal of Clinical Child Psychology 22(3):337-344.

HAMPEL, P \& PETERMANN, F. 2005. Age and gender effects on coping in children and adolescents. Journal of Youth and Adolescents 34(2):73-83. HEINZ, WR \& MARSHALL, VW. 2003. Social dynamics of the life course. Transitions, institutions and interrelations. New York City. NY. Aldine de Gruyter.

HEWITT, JP. 1979. Self and society. A symbolic interactionist social psychology. 2nd ed. London. Allyn \& Bacon, Inc.

HOYT, WD \& KOGAN, LR. 2001. Satisfaction with body image and peer relationships for males and females in a college environment. Sex Roles: A Journal of Research 45(3-4):199-216.

HUTCHINSON, SL, BALDWIN, CK \& OH, S. 2005 Adolescent coping. Exploring adolescents' leisurebased responses to stress. Leisure Sciences 28:115131.

JAMES, W. 1915. Psychology. New York City. NY. Henry Holt \& Co.

JAMES, W. 1961. (1892) Psychology: The briefer course. New York City. NY. Harper.

JONES, EE, FARINA, A, HASTROF, AH, MARKU, H, MILLER, DT \& SCOTT, RA. 1984. Social stigma. The psychology of marked relationships. New York City. NY. W.H. Freeman \& Company.

KLACZYNSKI, PA, GOOLD, KW \& MUDRY, JJ. 2004. Culture, obesity stereotypes, self-esteem and the "thin ideal": A social identity perspective. Journal of Youth and Adolescence 33(4):307-317.

LA GRECA, AM, SIEGEL, LJ, WALLANDER, JL \& WALKER, CE. 1992. Stress and coping in child health. New York City. NY. The Guilford Press.

LAZARUS, RS \& FOLKMAN, S. 1984. Stress, appraisal, and coping. New York City. NY. Springer.

LAZARUS, RS \& LAZARUS, BN. 1994. Passion and reason. Making sense of our emotions. New York City. NJ. Oxford University Press.

LEWIS, HB. 1971. Shame and guilt in neuroses. New York City. NY. Oxford University Press.

LEWIS, M. 1992. Shame. The exposed self. New York City. NY. Free Press.

MARCH, K. 2000. Who do I look like? Gaining a sense of self-authenticity through the physical reflections of others. Symbolic Interaction 23(4):359-374. MARKEY, CN, TINSLEY, BJ, ERICKSEN, AJ, OZER, 
DJ \& MARKEY, PM. 2002. Preadolescents' perceptions of females' body size and shape: Evolutionary and social learning perspectives. Journal of Youth and Adolescence 31(2):137-146.

MARSHALL, VW \& MUELLER, MM. 2004. Theoretical roots of the life course perspective. In Heins, WR \& Marshall, VW. (Eds). 2004. Social dynamics of the life course. New York City. NY. Aldine de Gruyter.

MEAD, GH. 1934. Mind, self, and society. Chichago. University of Chicago Press.

MURBERG, TA \& BRU, E. 2005. The role of coping styles as predictors of depressive symptoms among adolescents. A Prospective study. Scandinavian Journal of Psychology 46:385-393.

MWAMWENDA, TS. 1996. Educational psychology. An African perspective. 2nd ed. Durban. Butterworths. NOUNOPOULOS, A, ASHBY, JS \& GILMAN, R. 2006. Coping resources, perfectionism, and academic performance among adolescents. Psychology in the Schools 43(5):613-622.

OWENS, KB. 2002. Child and adolescent development. New York City. NY. Thomson Learning Inc. PIAGET, J. 1970. Piaget's Theory. In Mussen, PA. (Ed). 1970. Manual of child psychology. London. Wiley.

PIKO, B. 2001. Gender differences and similarities in adolescents' ways of coping. The Psychological Record 51:223-235.

PUHL, R \& BROWNELL, KD. 2003a. Ways of coping with obesity stigma: Review and conceptual analysis. Eating behaviours 4(1):53-78.

PUHL, R \& BROWNELL, KD. 2003b. Psycho-social origins of obesity stigma. Toward changing a powerful and pervasive bias. Obesity Reviews 4:213-227.

QUINN, DM \& CROCKER, J. 1999. When ideology hurts. Effects of belief in the Protestant ethic and feeling overweight on the psychological well-being of women. Journal of Personality and Social Psychology 77(2):402-414.

REBELO, MA. 2004. The influence of acculturation on the early adolescent-concept of black adolescents. MA Dissertation. Pretoria. University of Pretoria.

RICE, FP. 1995. Human development. A life-span approach. 2nd ed. Upper Saddle River. NJ. Prentice Hall.

SCRIVEN, A \& STEVENSON, V. 1998. Psychological development of young adolescents. Implications for health education practice. Health Education 3:89-94. SEGELKEN, R. 2005. Researchers view obesity from a life course perspective. Human Ecology 33(3):1417.

SHIBUTANI, T. 1955. Reference Groups as perspectives. American Journal of Sociology 60(6):562-569.

SHIBUTANI, T. 1961. Society and personality. An interactionist approach to social psychology. Englewood Cliffs. NJ. Prentice-Hall.

SHIBUTANI, T. 1962. Reference groups and social control. In Rose, AM. (Ed). 1962. Human behaviour and social processes - an interactionist approach. London. Routledge \& Kegan Paul.

SMOLAK, L. 2004. Body image in children and adolescents. Where do we go from here? Body Image 1 (1):15-28.

STONE, GP. 1962. Appearance and the early adolescent. In Rose, AM. (Ed). 1962. Human behaviour and social processes - an interactionist approach. London. Routledge \& Kegan Paul.

STURDEVANT, MS \& SPEAR, B. 2002. Adolescent psychosocial development. Journal of the American Dietetic Association 102(3):30-31.

TOMAKA, J \& BLASCOVICH, J. 1994. Effects of justice beliefs on cognitive appraisal and subjective, psychological and behavioural responses to potential stress. Journal of Personality and Social Psychology 67:732-740.

TURNER, SB. 1984. The body and society. New York City. NY. Basil Blackwell.

TWININGS, K. 1998. Success in psychology. London. John Murray.

VANDER WAL, JS \& THELEN, MH. 2000. Predictors of body image dissatisfaction in elementary-age school girls. Eating Behaviours 1(2):105-122.

VAN NIEKERK, L \& VAN DER SPUY, D. 1994. Tieners gereed vir die lewe! 2nd ed. Pretoria. JP van der Walt.

VIVIANI, F. 2006. Some aspects of the body image and early-self-perception in adolescents. Papers on Anthropology XV:302-309.

WEINER, B. 1986. An attributional theory of motivation and emotion. New York City. NY. Springer Verlag. 